\title{
Insulin Autoantibodies as Determined by Competitive Radiobinding Assay are Positively Correlated with Impaired Beta-Cell Function - The Ulm-Frankfurt Population Study
}

\author{
N. Yassin ${ }^{1}$, J. Seißler ${ }^{1}$, M. Glück ${ }^{1}$, B.O. Boehm ${ }^{2}$, E. Heinze ${ }^{3}$, E.F. Pfeiffer ${ }^{1}$, and W.A. Scherbaum ${ }^{1}$ \\ ${ }^{1}$ Abteilung Innere Medizin I, Universität Ulm, Ulm \\ ${ }^{2}$ Abteilung Endokrinologie, Universität Frankfurt, Frankfurt \\ ${ }^{3}$ Kinderklinik, Universität Ulm, Ulm
}

Summary. Out of a random population of 4208 non-diabetic pupils without a family history of Type I diabetes $44(1.05 \%)$ individuals had islet cell antibody (ICA) levels greater or equal to 5 Juvenile Diabetes Foundation (JDF) units. 39 of these ICA-positives could be repeatedly tested for circulating insulin autoantibodies (CIAA) using a competitive radiobinding assay. The results were compared with the insulin responses in the intravenous glucose tolerance tests (IVGTT) and with HLA types. Six pupils were positive for CIAA. All of them had complement-fixing ICA, and 5 of them were HLA-DR4 positive. Three of the 6 showed a first-phase insulin response below the first percentile of normal controls. Our data indicate that in population-based studies CIAA can be considered as a high risk marker for impaired beta-cell function in non-diabetic ICA-positive individuals.

Key words: CIAA - CF-ICA - Beta-cell function - IVGTT - HLA

Type I diabetes as well as the prediabetic period are characterized by the presence in the serum of islet-specific autoantibodies and an impaired firstphase insulin response to intravenous glucose [16, 18]. Insulin autoantibodies (IAA) were first described by Palmer et al. [13] in patients with newly diagnosed Type I (insulin-dependent) diabetes before insulin treatment, and they were subsequently also identified in non-diabetic first-degree relatives

Abbreviations : $\mathrm{CF}=$ complement-fixing $; \mathrm{CIAA}=$ circulating insulin autoantibodies; ELISA = enzyme-linked immunosorbent assay; HLA = human leukocyte antigen; IAA = insulin autoantibodies; ICA = cytoplasmic islet cell antibodies; IVGTT $=$ intravenous glucose tolerance test; JDF $=$ Juvenile Diabetes Foundation; RIA = radioimmunoassay of such patients $[1,2,7,17]$. Therefore, their possible role as predictive markers for the future development of Type I diabetes has attracted much attention.

Islet cell antibodies (ICA) are associated with newly diagnosed Type I diabetes and they have become indispensable tools for the initial screening to indicate the risk for the later development of the disease. However, ICA may be transiently positive and unrelated to diabetes [15], so that additional parameters should be evaluated. Recently autoantibodies against proinsulin were described in diabetic patients and their relatives, but their predictive value for the development of Type I diabetes is still unknown [11]. Eisenbarth [8] and Atkinson et al. [2] suggested that IAA determined by radioimmunoassay (RIA) may serve as highrisk markers in ICA-positive first-degree relatives, and time-dependent onset of Type I diabetes was also shown in life-table analyses, based on the level of IAA during the prediabetic period [23]. According to the data thus far available from family studies, IAA detected by ELISA seem to be unsuitable for such a prediction.

Although $90 \%$ of the cases of Type I diabetes have no family history of this disease, data on IAA detected by competitive radiobinding assay (CIAA) have not been reported from populationbased studies. We now studied CIAA in ICA positive individuals from a random population in order to assess their correlation with beta-cell insufficiency.

\section{Methods}

\section{Study Population}

4208 pupils (2292 females, 1916 males, age range 7-21 years; mean age 13.9 years) from 19 schools 
in the Ulm/Alb-Donau County, Germany, were primarily investigated between July 1988 and July 1989. The study was performed in accordance with the principles of the Declaration of Helsinki. Written consent was given by the local Ethical Committee, the Data Protection Council, individuals over 18 years of age, and the parents of children studied. $3 \mathrm{ml}$ of blood were collected from the antecubital vein. The sera were given coded numbers and stored at $-20^{\circ} \mathrm{C}$ until they were used for further testing.

Of the 4208 individuals initially screened, 44 $(1.04 \%)$ were ICA-positive. 39 of these ICA-positive pupils were available for further testing after 3 months, when CIAA were determined in fasting blood for the first time. Thus far, a follow up of 15 months has been performed in most of them.

\section{Controls}

The sera of 100 ICA-negative pupils without a family history of diabetes were taken to evaluate normal values of CIAA. They were 45 females and 55 males. The mean age of this group was 14 years, range 8-19 years. 39 age- and sex-matched ICAnegative class-mates of the ICA-positive individuals were taken as controls for CIAA determination. As we were not allowed by our Ethical committee to test for IVGTT's in normal children, 216 healthy ICA negative adults were taken as controls for insulin secretion.

193 randomly selected local control subjects ( 94 female, 99 males) and 30 ICA-positive type I diabetic individuals ( 15 females, 15 males) were taken as controls for HLA-DR typing. 1624 healthy blood donors were also HLA-typed to assess the frequencies of HLA-DR phenotypes.

\section{Primary Screening for Islet Cell Antibodies (ICA)}

Sera were tested by the standard indirect immunofluorescence test using $4 \mu \mathrm{m}$ unfixed cryostat sections of human pancreas as described [14]. Positive sera were then diluted until endpoint. In an international quality control study, our laboratory achieved values of $100 \%$ for specificity, $75 \%$ for sensitivity and consistency and $87 \%$ for validity (Third IDW ICA Proficiency Program; Lab ID No. 116, WAS). The same pancreas and procedure were used in the survey here described. ICA test results were transferred to Juvenile Diabetes Foundation (JDF) units using the standard curve provided for the workshop [6]. The lower limit of our assay is $5 \mathrm{JDF}$ units. The tests were carried out in a "blinded" manner by two investigators (G.T. and G.F.). In all ICA-positives, the sera were retested for ICA at intervals of 3 months.

\section{Complement-Fixing ICA (CF-ICA)}

ICA-positive sera were further tested for CF-ICA using an indirect immunofluorescence method, where serum of an ICA-negative healthy individual served as a source of complement [14]. This test was repeated every 3 months in all ICA-positive individuals.

\section{Blood Glucose Determination}

Blood glucose was tested in each of the sera with the hexokinase/G6P-DH method (Boehringer Mannheim, Germany) using an automatic Eppendorf analyzer.

\section{Intravenous Glucose Tolerance Test (IVGTT)}

ICA-positive individuals were tested by the IVGTT using the method described by Srikanta et al. [16]. After taking a $3 \mathrm{ml}$ fasting blood sample (time point zero), 0.5 g glucose $/ \mathrm{kg}$ body weight were administered intravenously over a period of $2 \mathrm{~min}$. Blood samples were then collected after 1, 3, 5, 10,20 , and $30 \mathrm{~min}$ and stored at $-70^{\circ} \mathrm{C}$ until further testing. Insulin immunoreactivity was determined by the CIS RIA-Kit (Griffe-sur-Yvette, France). The $1+3$ minutes plasma insulin levels were calculated to indicate the early-phase insulin peak reflecting the secretory capacity of beta-cells. Values below $48 \mu \mathrm{U} / \mathrm{ml}$, the first percentile of 216 normal controls (92 females, 128 males, mean age 29,5 years) were considered pathological. Individuals with a blunted first-phase insulin response were retested at intervals of 3 months, while all the others had a second IVGTT done after one year.

\section{Determination of Insulin Autoantibodies (CIAA)}

The protocol used for the competitive RIA detecting specific insulin binding followed the method described by Vardi et al. [20]. Briefly, two sets of tubes were prepared with equal amounts of serum $(150 \mu \mathrm{l} /$ tube). Supraphysiologic concentrations of cold insulin (equivalent to $300 \mu \mathrm{U} / \mathrm{ml}$ serum) were added to one set of tubes and incubated at $4^{\circ} \mathrm{C}$ for at least one hour. Then physiologic concentrations of ${ }^{125}$ I-labeled insulin (equivalent to $10 \mu \mathrm{U} /$ $\mathrm{ml}$ serum) were added to both sets of tubes, followed by a 7 days-incubation period at $4^{\circ} \mathrm{C}$. Bound insulin was separated by polyethylene glycol precipitation. Pellets were counted for $9 \mathrm{~min}$ 
in the gamma-counter. The difference in percent binding with and without excess unlabeled insulin was translated into the absolute amount of labeled hormone displaced from the binding sites by competition with cold ligand $(1 \mathrm{nU} / \mathrm{ml}=6.7 \times$ $10^{-6} \mathrm{pM}$ insulin precipitated). Participating at the First IAA Proficiency Test with this assay, our laboratory achieved a $100 \%$ specificity and consistency, $92 \%$ validity and $87 \%$ specificity (Lab ID No. 116, WAS).

\section{$H L A$ Serology}

HLA-DR typing was performed by the standard two-colour fluorescence technique according to van Rood and coworkers [19]. Only antisera of the 10th International HLA Workshop were used.

\section{Results}

44 individuals out of a random population of 4208 non-diabetic school-children without a family history of Type I diabetes $(1.05 \%)$ had ICA levels greater or equal to $10 \mathrm{JDF}$-units. 39 ICA-positive individuals could be tested for other parameters at follow-up investigations and 6 out of the 39 $(15.4 \%)$ were also positive for CF-ICA.

$33 / 39$ showed no additional pathological parameters during the whole follow-up period and they were therefore summarized in Table 1 (7-39).
At initial testing for CIAA $5 / 39(12.8 \%)$ ICApositive pupils, but none of their age- and sexmatched class-mate controls were positive for CIAA. All 5 CIAA-positive individuals also had CF-ICA (Table 1). 3 months later one more previously CIAA-negative pupil became positive (No. 4 - Figure 1), so that all individuals who showed CF-ICA were CIAA positive at one occasion during the follow-up.

HLA-DR3 and HLA-DR4 alleles were observed to be significantly increased in all ICA-positive individuals when compared to controls $(\mathrm{p}<$ $0.001)$. 5 of the 6 CF-ICA and CIAA-positive schoolchildren were HLA-DR4-positive, and 2 of the 5 were DR-4/3 heterozygous (Table 1 ).

When the IVGTT was performed for the first time, $2 / 39(5.1 \%)$ (No. 2 and No. 6 - Table 1$)$ showed a first-phase insulin response below the first percentile of normal controls $(<48 \mu \mathrm{U} / \mathrm{ml})$. A third individual (No. 3 - Fig. 1) showed a blunted first-phase insulin response of $44 \mu \mathrm{U} / \mathrm{ml}$ 3 months later. All 3 pupils with a pathological IVGTT were persistently ICA-positive. CF-ICA were persistently positive in 2 of them and they disappeared in one child during the follow-up (No. 6 - Fig. 1). CIAA were persistently positive in all 3 individuals over a period of 9-15 months.

Proband No. 2 became insulin-dependent 16 months after initial testing. This individual showed persistent ICA, CF-ICA and CIAA. CIAA had

Table 1. Correlation of circulating insulin autoantibodies with the presence of complement-fixing islet cell antibodies and a blunted 1st-phase insulin response in ICA-positive pupils

\begin{tabular}{|c|c|c|c|c|c|c|c|}
\hline \multirow[t]{2}{*}{$\begin{array}{l}\text { Pupil } \\
\text { (code No.) }\end{array}$} & \multirow[t]{2}{*}{$\begin{array}{l}\text { Age } \\
\text { (years) }\end{array}$} & \multirow[t]{2}{*}{$\begin{array}{l}\text { HLA-DR } \\
\text { type }\end{array}$} & \multirow[t]{2}{*}{$\begin{array}{l}\text { ICA } \\
\text { (JDF-units) }\end{array}$} & \multirow[t]{2}{*}{$\begin{array}{l}\text { CF-ICA } \\
\text { (titre) }\end{array}$} & \multirow[t]{2}{*}{$\begin{array}{l}\text { CIAA } \\
(\mathrm{nU} / \mathrm{ml})\end{array}$} & \multicolumn{2}{|c|}{$\begin{array}{l}\text { IVGTT } 1+3 \text { min insulin } \\
(\mu \mathrm{U} / \mathrm{ml})\end{array}$} \\
\hline & & & & & & initially & after 12 months \\
\hline $\begin{array}{l}1 \\
(8724882)\end{array}$ & 14 & 3.4 & 80 & $1 / 4$ & 178 & 77 & n.t. \\
\hline $\begin{array}{l}2 \\
(9905031)\end{array}$ & 15 & 1,2 & 60 & $1 / 2$ & 101 & 42 & $<7$ \\
\hline $\begin{array}{l}3 \\
(8722424)\end{array}$ & 12 & $4,-$ & 80 & $1 / 2$ & 49 & 85 & 44 \\
\hline $\begin{array}{l}4 \\
(8724860)\end{array}$ & 13 & 3,4 & 10 & $1 / 2$ & 10 & 58 & n.t. \\
\hline $\begin{array}{l}5 \\
(8723637)\end{array}$ & 11 & $4,-$ & 80 & $1 / 2$ & 241 & 205 & 152 \\
\hline $\begin{array}{l}6 \\
(8722221)\end{array}$ & 8 & $4, w 6$ & 40 & $1 / 1$ & 115 & 25 & 36 \\
\hline $7-33$ & $7-19$ & see text & positive & negative & negative & normal & \\
\hline
\end{tabular}

ICA = islet-cell antibodies, limit of detection is $5 \mathrm{JDF}$-units; CF-ICA = complement-fixing islet-cell antibodies; IAA $=$ circulating insulin autoantibodies; $\geq 45 \mathrm{nU} / \mathrm{ml}$ is taken as positive; IVGTT=intravenous glucose tolerance test, $<48 \mathrm{uU} / \mathrm{ml}$ is below the first percentile of normals 

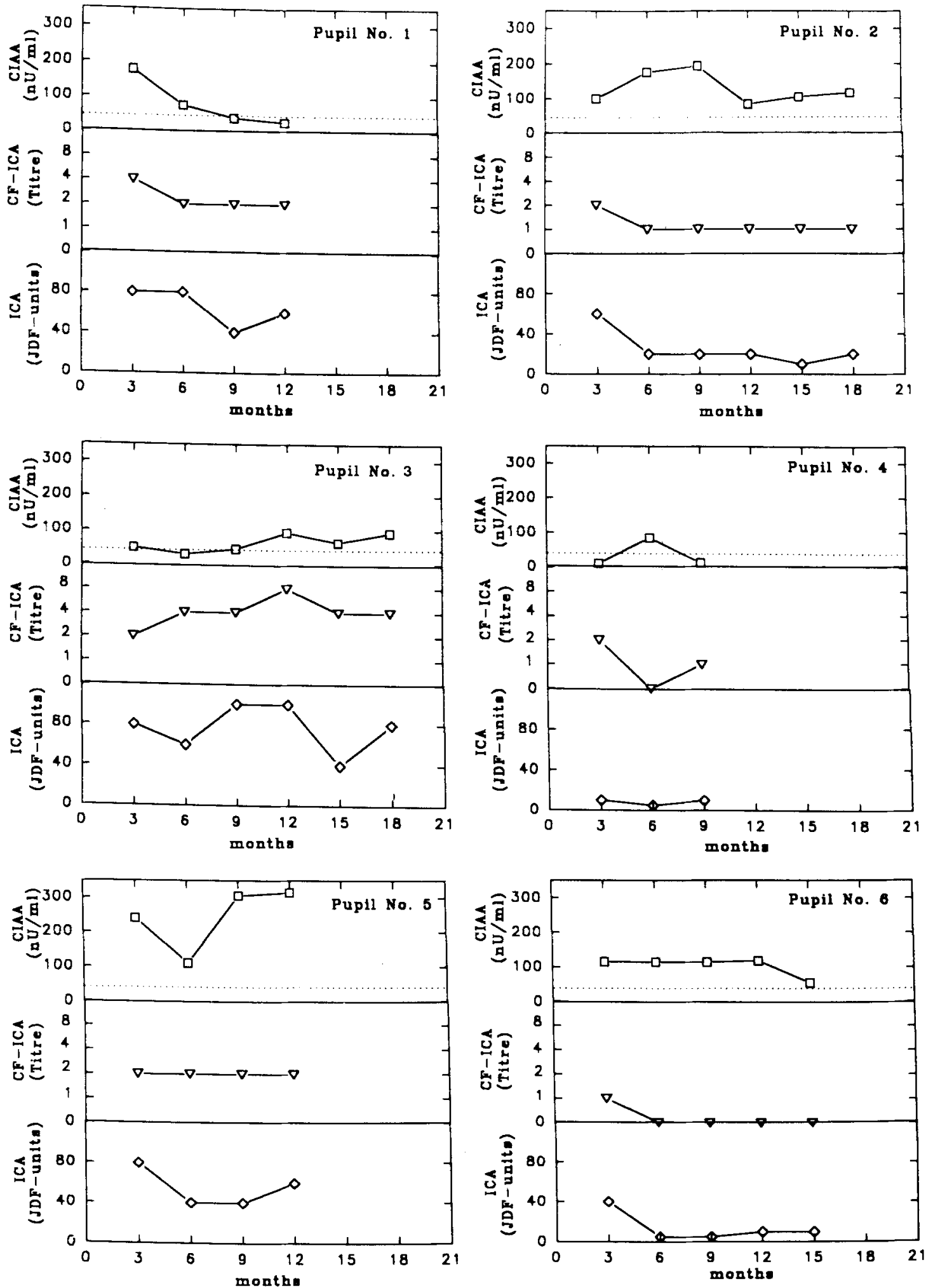

Fig. 1. Results of follow-up investigations of islet-cell antibodies (ICA), complement-fixing ICA and circulating insulin autoantibodies in ICA-positive pupils. ICA: islet-cell antibodies, given in Juvenile Diabetes Foundation (JDF)-units. CF-ICA: complementfixing ICA, given as titres. CIAA: circulating insulin autoantibodies measured by competitive radiobinding assay, results given in $\mathrm{nU} / \mathrm{ml}$ 
a mean of about $130 \mathrm{nU} / \mathrm{ml}$ over a period of 18 months.

\section{Discussion}

Insulin autoantibodies detected by competitive radiobinding assay (CIAA) have been shown to be high risk markers for the future development of Type I diabetes in non-affected first-degree relatives of Type I diabetic patients [9]. We were here able to show for the first time that CIAA are highly correlated with beta-cell deficiency in non-diabetic individuals from a random population. Out of 39 ICA-positive individuals aged 7-19 years, 6 had CIAA, and 3 of them had a first-phase insulin response below the first percentile of normals, which is thought to reflect a point of no return in the prediabetic state [17].

Since the mere presence of ICA in non-diabetic individuals is not necessarily followed by Type I diabetes, it is a major aim of ongoing studies to elucidate high-risk markers in ICA-positive individuals. It was shown by Bottazzo's group that CF-ICA are correlated with a high risk for the later development of Type I diabetes in first-degree relatives of such patients [18]. During an eight-year follow-up period, 16 out of 719 individuals became diabetic, 13 of whom were CF-ICA positive. Also the data of Betterle et al. [5] in their ten-year follow-up study of non-diabetic patients with an organ-specific autoimmune disease other than Type I diabetes support the predictive value of CF-ICA. CIAA were not determined in these studies. In our population-based investigation, 6 out of 4208 individuals were positive for CF-ICA and 3 of them had an insulin response below the first percentile of normals.

As not more than $10-15 \%$ of Type I diabetic patients have a family history of the disease, it is important to determine the prevalence and predictive value of various risk markers in the random population. So far, two European populationbased studies have been published. In the Spanish study an ELISA test was used for IAA determination [3], while in the Finnish study IAA were not determined at all [10].

The dispute on the best method to apply for the detection of insulin autoantibodies (IAA) has been subject of several IAA standardization workshops [12], which have shown that the results obtained by ELISAs do not correlate with the results obtained by radiobinding assays. In contrast to IAA determined by ELISA, CIAA are correlated with a high risk for the later development of Type I diabetes [22].
In the Caucasoid population, the HLA-DR3 and DR4 alleles are strongly correlated with Type I diabetes [4]. In the whole cohort of our ICApositive population, we found a significantly higher number of subjects with the HLA-DR4 allele when compared to local controls. In untreated patients, an association between insulin autoantibodies and HLA-DR3 or DR4 or both has been found by some authors [2,9], but not by others $[1,21]$. These differences may be due to the variance of assays used for the detection of IAA. In our study with a 7-days incubation period in the competitive radiobinding assay, five out of six HLA-DR-typed CIAA-positive individuals revealed the DR4 allele, suggesting a positive correlation.

Although the initial number of school-children screened is large, the positive cases found are few and the time of follow-up is relatively short to come to final conclusions. Yet, it already appears from our present data that the determination of CIAA in ICA positive non-diabetic individuals provides a valuable means to indicate impaired beta cell function which may allow further selection of individuals at high risk for the future development of Type I diabetes among ICA-positive non-diabetic individuals in a random population.

Acknowledgements: We thank Dr. G. Eisenbarth and Dr. A.G. Ziegler for supplying the protocol for CIAA determination and Prof. J.S. Soeldner for IVGTT data in normal controls. We are grateful to Gerlinde Trischler and Gisela Graf for their technical help. This work was supported by the Deutsche Forschungsgemeinschaft (Sche 225-3/2, Schwerpunkt "Ursachen und Folgen des Diabetes mellitus" and Scho 109/16-2), the Deutsche Diabetesstiftung (J.S. and B.O.B.) and the Ministry of Science, Baden-Württemberg (Landesmittel-Forschungsschwerpunkt Nr. 31 to WAS), a grant from the Wollheim-Stiftung (to BOB) and the Deutsche Akademische Austauschdienst, DAAD (to NY).

\section{References}

1. Arslanian SA, Becker DJ, Rabin R, Atchison M, Eberhardt M, Cavender D, Dorman J, Drasch AL (1985) Correlates of insulin antibodies in newly diagnosed children with insulin-dependent diabetes before insulin therapy. Diabetes 34:926-930

2. Atkinson MA, Maclaren NK, Riley WJ, Winter WE, Fisk DD, Spillar RP (1986) Are insulin autoantibodies markers for insulin-dependent diabetes mellitus? Diabetes 35:894898

3. Bergua M, Solé J, Marion G, Perez MC, Recasens A, Fernàndez $J$, Casamitjana $R$, Gomis $R$ (1987) Prevalence of islet cell antibodies, insulin antibodies and hyperglycaemia in 2291 schoolchildren. Diabetologia 30: 724-726

4. Bertrams J, Baur M (1984) Insulin-dependent diabetes mellitus. In: Albert ED, Baur MP, Mayr WR (eds) Histocompatibility Testing. Springer, Heidelberg, pp 348-358 
5. Betterle C, Presotto F, Pedini B, Moro L, Slack RS, Zanette F, Zanchetta R (1987) Islet cell and insulin autoantibodies in organ-specific autoimmune patients. Their behaviour and predictive value for the development of Type I (insulin-dependent) diabetes mellitus. A 10-year follow-up study. Diabetologia 30:292-297

6. Bonifacio E, Dawkins RL, Lernmark A (1987) Immunology and diabetes workshops: Report of the second international workshop on the standardization of cytoplasmic islet cell antibodies. Diabetologia 30:273

7. Dean BM, Becker F, McNally JM, Tarn AC, Schwartz G, Gale EAS, Bottazzo GF (1986) Insulin autoantibodies in the prediabetic period: correlation with islet cell antibodies and development of diabetes. Diabetologia 29:339-342

8. Eisenbarth GS (1990) Autoimmune serology in Type I diabetes and the prediabetic state. IDF Bulletin 35:40-43

9. Karjalainen J, Knip M, Mustonen A, Ilonen J, Akerblom HK (1986) Relation between insulin antibody and complement-fixing islet cell antibody at clinical diagnosis of IDDM. Diabetes 35:620-622

10. Karjalainen J (1990) Islet cell antibodies as predictive markers for IDDM in children with high background incidence of disease. Diabetes 39:1144-1150

11. Kuglin B, Gries FA, Kolb H (1988) Evidence of IgG autoantibodies against human proinsulin in patients with IDDM before insulin treatment. Diabetes 37:130-132

12. Kuglin B, Kolb H, Greenbaum C, Maclaren NK, Lernmark $\AA$, Palmer JP (1990) The Fourth International Workshop on the Standardisation of Insulin Autoantibody Measurement. Diabetologia 33:638-639

13. Palmer JP, Asplin CM, Clemons P, Lyen K, Tatpati O, Raghu PK, Paquette TL (1983) Insulin autoantibodies in insulin-dependent diabetics before insulin treatment. Science 222:1337-1339

14. Scherbaum WA, Mirakian AR, Pujol-Borrell R, Dean BM, Bottazzo GF (1986) Immunochemistry in the study and diagnosis of organ-specific autoimmune diseases. In: Polak JM, van Noorden S (eds) Immunochemistry. Modern Methods and Applications. Wright, Bristol, pp 456-476

15. Spencer KM, Dean BM, Lister J, Bottazzo GF (1984) Fluctuating islet cell autoimmunity in unaffected relatives of patients with insulin-dependent diabetes. Lancet $\mathrm{i}: 764-766$
16. Srikanta S, Ganda OP, Rabizadeh A, Soeldner JS, Eisenbarth GS (1985) First-degree relatives of patients with Type I diabetes mellitus, islet-cell antibodies and abnormal insulin secretion. N Engl J Med 313:461-464

17. Srikanta S, Ricker AT, McCulloch DK, Soeldner JS, Eisenbarth GS, Palmer JP (1986) Autoimmunity to insulin, betacell dysfunction, and development of insulin-dependent diabetes mellitus. Diabetes 35:139-142

18. Tarn AC, Thomas JM, Dean BM, Ingram D, Schwarz G, Bottazzo GF, Gale EAM (1988) Predicting insulin-dependent diabetes. Lancet i: $845-850$

19. Van Rood JJ, Van Leeuwen A, Ploem JS (1976) Simultaneous detection of two cell populations by two colour fluorescence and application of the recognition of B-cell determinants. Nature 262:796-797

20. Vardi P, Dib SA, Tuttleman M, Connelly JE, Grinbergs M, Rabizadeh A, Riley WJ, Maclaren NK, Eisenbarth GS (1987) Competitive insulin autoantibody assay. Prospective evaluation of subjects at high risk for development of Type I diabetes mellitus. Diabetes 36:1286-1291

21. Wilkin T, Hoskins PJ, Armitage M, Rodier M, Casey C, Diaz J-L, Pyke DA, Leslie RDG (1985) Value of insulin autoantibodies as serum markers for insulin-dependent diabetes mellitus. Lancet ii: $480-482$

22. Ziegler AG, Ziegler R, Jackson RA, Eisenbarth GS (1989a) Testing the linear destruction hypothesis in Type I diabetes: the Joslin study. In: Andreani D, Kolb H, Pozzilli P (eds) Immunotherapy of Type I diabetes. Wiley, London, pp 736 739

23. Ziegler AG, Ziegler R, Vardi P, Jackson RA, Soeldner JS, Eisenbarth GS (1989b) Life-table analysis of progression to diabetes of anti-insulin antibody-positive relatives of individuals with Type I diabetes. Diabetes 38:1320-1325

Received: March 1, 1991

Returned for revision: April 26, 1991

Accepted: May 13, 1991

Prof. Dr. W.A. Scherbaum

Abteilung Innere Medizin, Med. Klinik und Poliklinik

Universität Ulm

W-7900 Ulm, FRG 